\title{
Why New Corporate Law Arises: Implications for the 21st Century
}

Robert Thompson

Georgetown University, thompson@law.georgetown.edu

This paper can be downloaded free of charge from:

https://scholarship.law.georgetown.edu/facpub/1979

https://ssrn.com/abstract_id=2978741

Robert B. Thompson, Why New Corporate Law Arises: Implications for the 21st Century, in The Corporate Contract in Changing Times: Is the Law Keeping Up? (William Savitt, Steven Davidoff Solomon \& Randall Thomas eds., University of Chicago Press forthcoming) 


\title{
Forthcoming chapter from "The Corporate Contract in Changing Times: Is Law Keeping Up? (University of Chicago Press, Davidoff Solomon, Savitt, \& Thomas eds)
}

\author{
Why New Corporate Law Arises: Implications for the $21^{\text {st }}$ Century
}

Robert B. Thompson*

\begin{abstract}
Corporate law is facing calls for change more intense than those heard in decades. Shareholders are more aggressively pushing back against management. In turn, other corporate stakeholders express increasing concern about shareholders' use of their power for selfish reasons and the perceived pernicious impact of shareholder wealth maximization as a guide for corporate law. Why does corporate law change and how it might change now?

Corporate law changed regularly in the first half of our country's history. A series of innovations followed one after another during the nineteenth century-limited liability; general incorporation statutes; a strong shift to director-centric corporate governance; authorization of corporations holding stock in other corporations; and the disappearance of ultra vires and other limits on corporate behavior. By the arrival of the twentieth century all the key economic elements of the modern corporation were in view and corporate law settled into a stable pattern we still see today. State law abandoned its prior regulatory approach and its continual change in favor of a director-centric structure with expansive room for private ordering that has remained remarkably stable. Federal law stepped in to restrain economic concentration (antitrust law), to protect employees and consumers against corporate power (done by industry regulation, employment and consumer laws not corporate governance), to limit corporate political contributions, and to make recurring, if sporadic and non-comprehensive, efforts to enhance the role of shareholders against managers.
\end{abstract}

This chapter examines this history of change in corporate law in America, the dramatic and abrupt shift in the focus of state corporate law visible in last decade or so of the nineteenth century, the interactive pattern of state and federal law that has grown up over the second half of the country's history and prominent theories explaining what leads to corporate law change. Together these various strands suggest there will be no fundamental change in corporate law even in this time of visible stress to the now classic structure.

\section{Prior Changes in Corporate Law}

\section{A. Introduction}

Over the first decades of the nineteenth century, for profit corporations came to supplant religious, charitable and quasi-public (bridge or turnpike) entities as principal users of the corporate form. 
(Blumberg 1990). Corporate law changes reflected and facilitated this trend. By the end of the century the modern corporation was in view with the economic characteristics that are familiar to $21^{\text {st }}$ century lawyers and business people. The 1890s presented a key inflection point for corporate law. States abandoned their regulatory approach to corporations in favor of permissive laws that were directorcentric in their allocation of power and left ample room for market decision-making, contracting and private ordering. The government's regulatory impulse did not disappear, however, but came to be expressed in various regulatory regimes in federal law-e.g. antitrust, worker protection and the parts of federal securities laws that addressed corporate governance.

\section{B. Changes over the $19^{\text {th }}$ Century}

Corporations evolved dramatically over the nineteenth century in America accompanied by recurring changes in corporate law. The legal changes occurred incrementally among the various states over multiple decades, often with each change occurring in partial steps in an individual state making the national change seem even more incremental. The statutory changes in turn reflected fundamental economic and financial changes that were taking place on the ground that continued to evolve. By the end of the century these various trends had jelled into a legal form we would recognize as the modern corporation and a regulatory structure that would be familiar to modern corporate lawyers. The components of this dramatic transformation of the corporation and its regulatory structure included: (1) Growth in the number of corporations and the increasing dominance of for profit entities; (2) limited liability for shareholders becoming the usual rule; (3) the move from special legislative chartering of each corporation to general incorporation laws; (4) evolution in the corporate form to facilitate centralized management and the rise of middle management in business to take greater advantage of this corporate characteristic; (5) public trading of stocks; and (6) permitting corporations to own stock in other corporations.

\section{Growth in the number of incorporations and the increasing dominance of for profit entities}

Joseph Ellis has described the move to the Constitution from the Declaration of Independence (and the weak Articles of Confederation that connected the newly independent states) as a second American revolution that turned on a change in the size of the world that Americans defined for themselves. (Ellis 2015). In the colonial period the geographic space citizens considered relevant for their political and business life was small, perhaps 30 miles; giving powers to a national government seemed too likely to reprise the oppression of the British crown against which the revolution had been fought. But the dysfunctionality of the confederation government, and perhaps some sense of the economic possibilities in a larger republic, led to a change in the form of government facilitating a broadened geographic frame of reference for politics that would soon be followed in American business. Over time there was opportunity for, and a greater need for, enterprises which assembled the capital from more than one person (Livermore 1939) and over time improvements in transportation and machinery increased the size of the market in which entrepreneurs could compete effectively. The result was a dramatic increase in the number of corporations, particularly for-profit corporations in the early $19^{\text {th }}$ century. 
Some of the most visible early nineteenth century corporations were for bridges or turnpike companies, purposes needed by the community but financed with private funds under a governmental charter and leading to a close association in the minds of the public between specially chartered corporations and worries about privilege and monopoly. Banking corporations were common and the subject of much of the Supreme Court litigation of the period (Blair \& Pollman 2015) raising questions of how to regulate entitles affecting the money supply and similar issues that invoked core pubic issues. By the 1830s, manufacturing corporations exceeded those in banking, insurance, and public service and the number was growing (Blumberg 1990); more companies were incorporated in the decades of the 1850s in Illinois than in the entire first half of the century (Dodd 1936).

\section{Limited liability}

As the size of markets grew and the need for capital in a particular business, limited liability was seen as a way to encourage entrepreneurial risk-taking. Several states adopted such rules in the first two decades of the nineteenth century. Massachusetts moved to limited liability for shareholders in 1830 and this rule became common in other states for corporations. Even so, it was not complete insulation from limited liability. Double liability, subjecting shareholders to personal liability for corporate obligations beyond their original investment up to an additional sum equal to that amount, remained the norm for the remainder of the century (and continued for California corporations and for national banks into the middle of the twentieth century) (Horwitz 1986).

\section{General incorporation statutes}

Concerns about privileges provided to incorporated businesses at the expense of the larger population, mixed in with Jacksonian opposition to re-chartering the Bank of the United States (banks, generally being one of the most visible groups of incorporated entities) led to passage of general incorporation statutes in some states in the 1830s and 1840s and in almost all states by 1875 (Hamil 1999). This may perhaps be the largest single statutory change for corporate law over the nineteenth century, but consistent with the other changes, it happened incrementally-four states in the 1830s, three in the 1850s and continuing to build (Hilt 2008). Even as the states moved to provide general incorporation, many of them did not prohibit state legislatures from continuing to provide special charters to individual companies on whatever terms the legislature desired. Delaware, for example, had a general incorporation statute as early as 1875 (and relaxed the conditions for the use of the general statute in 1883); even so, in 1897, just before Delaware's modern statute of 1899, the number of special charters (115) was more than 11 times greater than the 10 entities that used the general incorporation law for that same year (Arsht 1976).

Eric Hilt traced the impact of Massachusetts's general corporation act of 1851, which was one of those states that continued to retain special chartering from the legislature after enacting a general incorporation statute. He found that firms created under the general act were "strikingly different from either firms chartered prior to 1851" (when special chartering was the only option) or using the special charter route after 1851 . They were more diffuse in their industries and geography than the specially chartered firms, were significantly smaller with fewer shareholders, and had much higher degrees of managerial ownership (Hilt 2008). 


\section{Centralized management}

Centralized management has long been an advantage of the corporate form, but its use in business corporations changed dramatically in the $19^{\text {th }}$ century, for both legal and economic reasons. Educational and other charitable and non-profit corporations had previously received charters that put control in a board of trustees or directors. Livermore's treatment of land companies on the western frontier before and after the Revolutionary War shows some degree of centralized governance in these business firms even without charters in a setting where citizens were making "side" investments to their everyday commercial pursuits (Livermore 1939).

General use of centralized management was later in coming than the prior two characteristics of limited liability and general incorporation just described. New Deal Supreme Court Justice Wiley Rutledge, in his earlier role as a corporations law professor, observed that "the general incorporation laws of the nineteenth century were designed primarily to extend the privilege of limited liability to what may be termed 'incorporated partnerships' and relatively local joint stock companies rather than the creation of institutions national in the spread of their securities and activities."(Rutledge 1937). Noted business historian Alfred Chandler similarly described the increasing use of the incorporated stock company in the early $19^{\text {th }}$ century, but through the 1840 s he saw no change in the relatively decentralized governance characteristics that still proved satisfactory for most businesses. (Chandler 1977).

Over the latter half of the nineteenth century there was a gradual decline of the importance of the general meeting of shareholders as reflected in the broadening power exercised by directors. Dodd noted, for example, the very broad powers given directors in general incorporation acts such as that of Illinois in 1872 (Dodd 1936). Horwitz identified this late $19^{\text {th }}$ century shifting of power away from shareholders to directors so that after 1900 directors were treated "as equivalent to the corporation itself."(Horwitz 1986 at 182).

The legal changes reflected the evolution in market and financial conditions after the Civil-War when innovations propelled by the industrial revolution and changes in transportation, manufacturing and distribution increased the scope of markets in which firms could compete. Middle management that had not earlier existed became a common occurrence in corporations and managers who did not own a majority of shares acquired effective control of many firms. Depending on how businesses became large in this new business environment, some firms whose internal growth was sufficient to meet their capital needs became managerial under the control of the founders or family. In contrast, firms that needed outside capital to become large and take advantage of the new economies of scale were run by managers with only a minority of stock ownership (Chandler 1977). Once statutes provided for control by directors, as set out in the early Delaware general incorporation statutes described below, and provided for director appointment of other officers and agents, the statutory structure was sufficiently malleable to permit the growth of top executives and middle managers as economic conditions evolved. 


\section{Public trading of stocks}

Like centralized control just described, public trading of stock reflected the changing possibilities provided by evolving markets and finance. Early general corporation statutes proclaimed stock to be personal property and provided for its sale by means set forth in the bylaws (Hilt 2015 at 9). After the Civil War stock exchanges expanded to include a larger number of manufacturing firms that effectively provided free transferability across a broad range of America's largest firms without the need for any bylaw provision or private contracting (Navin \& Sears 1955 at 107-8). By the end of the $19^{\text {th }}$ century, free transferability had developed to the point where it became usual characteristic of the modern conception of a corporation.

6. Recognition of holding companies and removal of statutory limits on size, purpose and duration

The last characteristic of the modern corporation to chronologically appear in the nineteenth century was the statutory grant to corporations to own stock in other corporations. Changes in economic and financial conditions showed the benefit of controlling entities operating in multiple states. Yet doing business outside the state of incorporation presented some difficulty for corporations given a Supreme Court decision in 1839 that declined to find such a constitutional right for corporations. ${ }^{i}$ Entrepreneurs such as John D. Rockefeller looked to trusts as a way to structure the burgeoning oil refinery business that he was assembling." He organized the South Improvement Co. in the 1870s and then made Standard Oil into a trust in the 1880 s, providing the same centralized control available within the corporate form but without the limits in operating across state lines or owning stock in other corporations (Chandler 1977 at 323). When state courts in Louisiana, New York, and Ohio found trusts in cotton, sugar and oil violated their state law of corporations, New Jersey came to their rescue. In 1888 and 1889, amendments to the New Jersey corporations statute authorized corporations to own stock in other corporations. (Horwitz 1986 at 195).

\section{The Modern Corporation in View: The Inflection Point in the Late $19^{\text {th }}$ Century Shaping Corporate Law}

By the late 1880s, all of the elements of the modern corporation were in view (if not yet spread to all corners of the country.) It was a coming together of the expansion in the geographic and industrial scale that could be supported in the growing American economy and the administrative ascendancy of middle managers (Chandler 1977). Corporate law reflected and facilitated these changes; the liberalizations of New Jersey's general incorporation act of 1896 provided no limit on a corporation's duration, permitted incorporation for any lawful purpose and to carry on business in other jurisdictions, authorized mergers and consolidations, and enabled director amendments of bylaws (Strine \& Walter 2015). New Jersey became the home not just of Standard Oil but a large percentage of larger New York businesses. The race among the states was on with New Jersey the early favorite and Delaware stepping into New Jersey's shoes after that state's governor, Woodrow Wilson, pushed reform on his way to Washington to assume the presidency (Yablon 2007). During this period there also was a decline in other traditional restrictions on corporations --the disappearance of ultra vires and quo warranto 
actions that had been used to limit corporation's acts-- and a similar shriveling of state efforts to assert control over foreign corporations. (Horwitz 1986).

Here we see a wholesale state law abandonment of the prior regulatory approach to corporations in favor of a permissive director-centric approach with more room for private ordering that still characterizes American corporate law. Joel Seligman termed it a "revolution wrought in the law of corporations" that led to general incorporation statutes that "turned corporate law inside out." (Seligman 1976). Similarly, Justice (then professor) Rutledge described the New Jersey law of 1887-1891 as "destined eventually to reverse the historic policy of the states [and] to place state policy fundamentally in opposition to that of the Federal government."(Rutledge 1937 at 311-312).

This point of inflection was recurringly described as following from the underlying changes in an economy where size seemed inevitable. Rutledge characterizes prior corporations statutes ("horse and buggy statutes" he called them) as

\begin{abstract}
antiquated and inadequate to the needs of modern high-powered
business organized, on a mass-production scale..... It may be that a society organized as broadly as ours is upon the basis of machines and under the capitalistic system, changing as rapidly as it has done during the last fifty years, can operate only with highly mobile industrial and financial organizations. If this is true, and the tendency certainly seems to have been in this direction..., the power phases of the recent corporate development have been necessary phases of that growth.
\end{abstract}

(Rutledge 1937 at 311-312).

Morton Horwitz, even less of a champion of big business than Rutledge, noted a "stunning reversal in American economic thought" in this period to "defend and justify as inevitable" the emergence of large-scale corporate concentration, pointing to the writings of economist Henry Adams and to the influence of the "natural entity" theory of the corporate entity whose main effect "was to legitimate large scale enterprise and to destroy any special basis for state regulation." (Horwitz 1986 at 221) When Columbia University President Nicholas Murray Butler declared the limited liability corporation as "the greatest single discovery of modern times...[e]ven steam and electricity are far less important...and they would be of comparative impotence without it...." (Butler 1912 at 82), he based his claim on this fundamental economic shift in society:

The era of unrestricted individual competition has gone forever...taken up into a new and larger principle of cooperation...It cannot be stopped.

It ought not to be stopped. It is not in the public interest that it be stopped.... This new movement of cooperation has manifested itself in the last sixty or seventy years chiefly in the limited liability corporation.

For some this belief led to a conclusion that "legal forms cannot interfere with the natural evolution of the economy," expressed in support of general incorporation acts that did not restrict corporations [Bostwick 1899]. The permissive approach to state corporate law that has prevailed since the late $19^{\text {th }}$ century is consistent with this version. For others, including Butler and progressives of the day, this 
economic fact led to more support for intense federal regulation that found expression in antitrust and railroad regulation from the late $19^{\text {th }}$ century (Butler 1912) or federal securities laws that increasingly has provided mandatory federal rules of corporate governance. The reality is that the corporate law of the $19^{\text {th }}$ century has continued in two streams, state corporations law that corporate lawyers of the late $19^{\text {th }}$ century would still recognize as familiar and federal law of various flavors that has experienced a much greater degree of change. Justice Louis Brandeis's lament in his dissent in the Liggett case in $1933^{\mathrm{iii}}$ that corporate law had been denuded of all its traditional constraints cannot be fully appreciated today with considering the mantle of regulation assumed by federal law in the time since.

\section{Changes in Corporate Law the Second Half of the Country's History}

Since the point of inflection discussed in the previous section, the pattern of change in corporate law illustrates two divergent paths. State corporate law today is still the governance system whose core points would be recognized by the cutting-edge late $19^{\text {th }}$ century corporate lawyers who drafted the statutes of that period. Federal law reflects a completely different pattern of regular and diffuse changes. The two strands existing simultaneously are a necessary foundation to the theory of changes discussed in Part II.

\section{State corporate law}

Modern corporate law reflects three core principles that can be directly traced to $19^{\text {th }}$ century corporate law and an important and sometimes overlooked fourth principle acknowledging how the business and economic foundation on which the law is places fundamentally reshapes the reality of those legal rules.

Rule \#1: Directors rule (most of the time). This principle derives from a bedrock point of corporate law found in all American corporate statutes including Delaware's $\S 141$ and $\S 8.01$ (b) of the Model Business Corporation Act that "all" corporate powers shall be exercised by the board. Empowering a centralized group to speak for the entity provides efficiency benefits in an economy where shareholding is widely dispersed. As a centralized decision-maker, the board can negotiate on behalf of shareholders and other constituencies. The wording of today's section 141 comes directly from Section 20 of Delaware's 1899 General Corporation Act: "The business of every corporation organized under the provisions of this Act shall be managed by a board..." ${ }^{\prime i v}$ and tracks similar language in Delaware's 1883 statute. The business judgment rule, a common law presumption of judicial deference to director decisions, reflects this same principle and also dates to the nineteenth century (Smith 1999). At the same time, directors with this broad power to direct other people's money might not pay the attention to the enterprise that the shareholders would like them to pay or may use their power to benefit themselves or the managers who they fail to monitor sufficiently. This leads to Rules 2 and 3.

Rule \#2: Shareholders are empowered to do only three things - they vote, sell, and sue, and only in limited doses. Shareholders are not given plenary powers to decide corporate policy. (Thompson 2016). Rather, they are conceived as simple actors able only to perform three basic functions. First, they are permitted to elect directors once a year and vote on mergers and other fundamental changes 
(provided the directors have decided they first agreed to such a transaction). Shareholder power to vote to amend the corporation's bylaws, in some situations without the board playing a gate-keeping role, has taken on broader importance in recent years. Second, shareholders can sell their shares, either in the market or in response to a tender offer made to them by a bidder seeking to acquire control. Third, they can, in some limited situations, sue for violation of statutes or fiduciary duties.

The current language of Delaware §211(b) specifying stockholder election of directors at an annual meeting tracks the language of the 1899 Act and parallels the same principle written into the 1883 Act. ${ }^{v}$ Today's language empowering stockholder to make and alter bylaws also dates from the 1899 statute along with the enabling language that this authority may be conferred on directors. These precise specifications of shareholder power contrast to common provisions of special incorporation statutes that focused corporate governance on the general meeting of shareholders. Indeed, Delaware's first general incorporation act, enacted in 1875, was silent on director control. These limited powers retained for shareholders in the time since reflect the concern that directors, while providing the advantages of centralized control, may, if unconstrained, act in ways that benefit themselves or otherwise harm shareholders. Shareholders, so the argument goes, are best positioned as the residual claimant of the enterprise to perform this monitoring function. (Thompson 2016).

Rule \#3: Judicial review provides a check agency power via fiduciary duties and resolve disputes at the boundary of director and shareholder power. American corporate law relies on courts to constrain director decisions (and possible abuse of their centralized power) by enforcing fiduciary duties of care and loyalty and sometimes resolve overlap between directors and shareholder realms. The early general incorporation acts were largely silent, as today's Delaware statute still is, as to directors' and officers' duties, so this space has been occupied by the courts. One of the key mid- $20^{\text {th }}$ century drafters of the current Delaware statute concluded that in the post-1899 world Delaware courts "promptly asserted the power of the Delaware judiciary to prevent corporate fraud and the inequitable use of corporate machinery by management." (Arsht 1976 at 1). That severely telescopes the "build out" of Delaware common law of fiduciary duty that largely occurred much later in the $20^{\text {th }}$ century. "Entire fairness" cases can be found prior to World War II but it took until the 1970s and 1980s to see the complex review structure of Unocal, Revlon and Blasius and the even more elaborate use of special committees and other internal corporate governance to cleanse possible director incapacity that have followed (Davidoff Solomon \& Thomas 2016).

Rule \# 4. Legal rules defer to the business and economic reality that managers usually are the first mover in corporate governance. Reading only the statutes or common law rules descried above would still leave one with a fundamental misunderstanding of American corporate governance. These legal rules have intentionally been placed atop a business and economic reality where there are efficiencies from a separation of function among shareholders, directors and managers and where a managerial hierarchy will often be the most effective decision-maker for the firm. This means that managers will usually be the first mover in corporate governance. That all-encompassing director power of Rule \# 1 will only be used intermittently when managers are disabled by conflict, or in times of crisis or egregious shortfalls in care. Shareholder power in its more limited space described above will be used even more intermittently. This shared power governance structure leaves substantial room for 
private ordering as each of these groups push back against the other. Managers threaten not to cooperate (Badawi 2014). Shareholders push directors and management to change even without seeking to take over the company, as was more common in the hostile takeover world of the late 1960s or early 1980s. Delaware courts seem to understand that within this shared power system keeping all players in the game is an important judicial function, so that each lives to fight another day and effective governance requires the continued interaction of the parties. (Thompson 2016).

This is not to say, however, that directors and managers do not have the central position under state law governance. It would be misdirectional to characterize Delaware law as shareholder friendly because its law lacks some of the severe antitakeover statutes of other states. Delaware's early blessing of poison pills and its Supreme Court's refusal to rein in that use of director power in all but the most egregious cases is more telling than a host of rarely used antitakeover statutes. Relative to the focus of this chapter on why law changes, this gives the governance structure in state corporate law a much more stable look while leaving considerable room for contracting and other private ordering within the broad boundaries set by the legal governance structure.

\section{Federal Law Affecting Corporations}

As state corporations law took a less regulatory approach at the end of the nineteenth century, federal law occupied the regulatory space that the states abandoned and also partially advanced into the manager-director-shareholder governance structure that became the focus of state corporations laws in the twentieth century. The first move focused on direct regulation of corporations as their conduct affects the public or subgroups such as consumers or workers (i.e. outsiders to the internal governance space just mentioned). The second move often sought to bolster shareholders in their interaction with boards and managers and to limit the broad space for those actors that state corporate law provided.

a. Federal law picking up the traditional regulation of corporate behavior that may adversely impact the public and groups outside the internal governance structure provided by twentieth century state corporate law

From the founding of the republic, corporate law had reflected mistrust of the corporate form based, for example, on size or fear of monopoly or special privilege, leading to recurring limits on purpose, size, or duration of these entities. As the state law changes discussed in Part IB embraced the potential for growth that the corporate form could provide in a changing economy this regulatory impulse did not disappear; rather it moved to a different level of government. Even before New Jersey had completed its shift to a laissez-faire statute that freed Standard Oil and other large corporations of the traditional limits of state corporate law, Congress passed the Sherman Act in 1890, providing a federal venue to challenge monopolies and other anti-competitive behavior. Indeed later interpretations of the Sherman Act and additional federal laws led to the breakup of trusts in refining and other businesses. Direct industry regulation, such as over railroads, grew after enactment of the Interstate Commerce Act passed shortly before the Sherman Act. In the early twentieth century, the Tillman Act limited the ability of corporations to make political contributions. The Federal Trade Act bolstered the antitrust powers of the federal government and provided consumer protection, largely 
against corporations. Another generation later, the New Deal brought a hosts of new governmental controls over the business activities of corporations vis a vis consumers, employees and the public. Much of this regulation reflects the nature of the fears that had generated the direct regulation of corporations in the first half of the country's history, but which had disappeared from state corporate law with changes triggered in the late nineteenth century.

\section{b. Federal law reflecting dissatisfaction with the governance balance in the space that state law had retained.}

As state law narrowed its corporate law to focus on the relative governance rights of shareholders, managers and officers, Congress did not provide a comprehensive set of federal rules as it had done in the areas just discussed, but neither was it willing to leave undisturbed the state law balance in corporate governance. Three times during the twentieth century there were highly visible movements to federalize corporate law-during the Progressive movement at the beginning of the century when three consecutive presidents favored federal incorporation statutes, during the beginning of the New Deal when the government contemplated responses to the Great Depression, and in the latter part of the century in the debate over the "race to the bottom" or "top". Federal incorporation did not result from any of those debates, but the result has been a series of federal intrusions into corporate governance, a bi-furcation between state and federal lawmakers that is highly relevant in the discussion of why corporate law changes (Thompson \& Sale 2003):

- The disclosure requirements of the Securities Exchange Act of 1934, later expanded by the Williams Act in 1968, sought to empower shareholders (vis a vis directors and centralized managers) when they voted or sold their shares, a dramatic governance addition to state corporations statutes still have very little in terms of what must be disclosed before shareholders act;

- Rule 14a-8 (promulgated in 1942) was one of many efforts of the Securities and Exchange Commission over the last 80 years to enhance the position of shareholders in the state governance structure described above, by, for example, creating a forum for shareholders to pursue proposals about corporate governance;

- The federal government has been increasingly willing to fill in the duties of managers (about which state law is almost completely silent) by, for example, specifying legal duties of the chief executive officers and chief financial officers and providing claw back of compensation in certain circumstances;

- Twenty-first century federal law has even specified the makeup of the board of directors, an issue at the very core of state governance, by requiring boards have key committees made up of independent directors, something that state law is silent about, leaving such questions to private ordering.

Recurring changes that have taken place in the federal space present a completely different pattern than what has happened in state law. Predicting when law will change requires examining the prevailing approach followed at each level of government, and even more, the interaction between them. 


\section{Why Does Law Change?}

\section{A. Theories on Why Law Changes}

Different theories have been suggested as to what would cause laws to change. Changes in the underlying economy, from inventions to demographic changes to trade relationships would seem an obvious candidate. The changes in the American economy in the nineteenth century described in Part I suggests such a pattern. Change in the legal system could have a similar effect, as was common in various countries after the fall of the Berlin Wall.

Stuart Banner suggests such a theory would be too broad. In the context of a discussion about the impact of technological advances on securities trading, Banner argues such changes alone would not be sufficient: "If one wants to know what future events would be most likely to persuade governments [to enact new regulatory laws] the answer is not new developments in information technology. The answer is a crash." (Banner 1997 at 855). His conclusion, reflecting 300 years of securities trading is that as long as securities markets are rising or holding steady, new regulation is held in check "by the simple fact that too many people have been making too much money to favor regulation restricting trading. But when prices drop much of that opposition to regulation is removed. People who are proponents of securities trading in good times become critics in bad."

That theory does well in explaining changes to American securities regulation-and the parts of corporate conduct that Congress has used the federal securities laws to reach. The crash of 1929 was followed by the Great Depression and the federal securities laws of the New Deal. The Great Recession of recent years included a painful crash and precipitated the reforms of the Dodd-Frank Act of 2010. The smaller market reaction at the time of the Enron scandal led to the Sarbanes-Oxley Act of 2002. Together, those legal responses to financial crises cover the list of federal changes to "internal" corporate law identified in the previous section. But the theory seems to do less well in explaining the series of changes to state corporate law in the nineteenth century and the relative stability of state corporate law since then.

Much of the debate on the change in corporate law has focused on theories surrounding interest groups. William Cary writing in 1974 but reflecting ideas going back to New Jersey's ascent in the 1890s, argued that states compete for incorporations by making their laws favorable to insiders who realistically make the choices as to where to incorporate with the result being a race to the bottom among the states (Cary 1974). Ralph Winter responded that if there is a race it is to the top not the bottom, propelled by the power of markets. Winter argued that if a corporation chose a place of incorporation that produced inferior results for its shareholders they would invest in businesses from other jurisdictions with different rules. (Winter 1977).

Whatever the result of the debate about the direction of the race among the various states (and many articles have been written and empirical data gathered as to the relative performance of corporations formed in Delaware and other states), the pattern of state and federal law set out above suggests the limitations of any such theory that considers only state competing against each other. Mark Roe has shown that even if Delaware has the instincts that Cary believed, it did the fear that the 
federal government will preempt all of state law keeps Delaware from going very far in that direction. (Roe 2003). It seems, even more than Roe has suggested, that there is a lock-in; all state laws are locked in to a statute that prefers control in directors and managers and the ability of the parties to freely contract about the governance system. If economic conditions change so that is not the preferred result, the new law will most surely come from the federal government not the states as discussed more fully below.

\section{B. Application in the Current Context}

1. Stress on the Classic System

Contemporary developments in the corporate space are putting more stress on the classic governance system. First, technology has dramatically lowered the costs of gathering and storing information and lowered the costs of communicating across markets, such as among shareholders in a publicly held corporation, making it easier for shareholders to challenge a centralized hierarchy. Second, changes in how the United States has chosen to fund worker retirement has created a different census of shareholders with incentives and conflicts that have diverged from traditional mom and pop shareholders that typified shareholders of publicly-held corporations in earlier generations. Seventy percent or more of the equity in American public corporations is owned by institutions acting as intermediaries for beneficiaries such as individuals or nonprofit educational and charitable entities.

A majority of American stock is in the hands of a particular kind of institutional investormutual funds or similar investments within employer-sponsored retirement plans given preferred tax status by the federal government and providing a vehicle for employees' saving for retirement or their children's college. (Edelman, Thomas \& Thompson 2014). The business plan for these funds, directed toward getting employers to include the fund among the small number of funds offered in the plan made available to employees of that particular company, gives the funds little reason to vote the shares that they control. (Gilson \& Gordon 2013). Any money spent on corporate governance in portfolio companies only increases costs while benefits are shared by other funds holding shares in the same portfolio company who have not incurred those costs. In such a setting, dollars spent for voting can lower the active fund's relative performance, a common metric plan sponsors use in deciding which funds to include in a company's plan.

Yet federal agencies (first under laws protecting employees and their retirement and more recently under laws directed to protect investors) now require intermediaries to vote the shares that they control and have expanded the number of issues on which shareholders vote, as compared to the limited list specified in state corporate law. The urgent need of institutional investors to be informed about these votes, and their lack of incentive to spend much money in the process, created an opening for a new set of agents in the voting process - proxy advisory firms. Such firms focus on providing information and voting services to institutional investors by gathering information about each of the votes to be held at public firms and then distributing that information for a fee to the many institutional investors owning shares in that company. Their efficiencies extend to tracking and submitting tens of 
thousands of votes cast each year by institutions. Moreover, these advisory firms have developed expertise on issues of corporate governance. A small group of proxy advisory firms has grown up over the last twenty-five years with Institutional Shareholder Services as the most visible (Edelman, Thomas \& Thompson 2014).

For most of the history of American corporate law it made little economic sense for shareholders to use the powers given them under state corporate law even with the federal enhancements--the collective action problems were too great when one shareholder with a miniscule portion of the equity would have to spend an amount for litigating or voting that would quickly exceed what it could hope to get back from the pro rata change in the value of its stock from any successful outcome. The dominant strategy for shareholders unhappy with their managers was the Wall Street Rule to simply sell the stock. (Schwartz 1978). In the contemporary governance setting set out above, one group of institutional investors, activist hedge funds, has figured out a way to make shareholder voting profitable. The organization, regulation and business plans followed by hedge funds give them high powered incentives to seek out relatively risky investments that can produce above-average returns. The subset of hedge funds focused on active governance seek out situations where a change in the target company's financial strategy (e.g. a dividend or stock buyback) can produce short term gains for shareholders. The activist shareholders' business plan (e.g. high leverage) means they don't want to commit funds sufficient to acquire control of the company. Crucially for their strategy, mutual funds and other institutional investors that own the bulk of the equity as described above (and the proxy advisory firms who advise institutions) are sometimes willing to support such proposals. At least this combination has occurred enough to push directors and managers to share the usual levers of corporate power when activists come calling.

A concern about too much short-termism and possible shareholder overreaching has opened a new chapter of a long-running corporate governance debate. For example, Delaware's Chief Justice Leo Strine, a learned and prescient observer of all things corporate, has suggested a series of proposed governance changes designed to: 1 ) align the intermediaries that control the funds invested in American equities with the long-term values of end users for whom those funds are invested; 2) reducing and sharpening the number of votes put before shareholders so as to not "overwhelm" the capacity of the institutional investor community "to actually think in a serious manner how to vote"; and 3) regulating the activist shareholders using current governance procedures by requiring more skin in the game for those making shareholder proposals and obtaining additional disclosure for those who are seeking shareholder votes on changes in corporate policy. (Strine 2014).

\section{How Might Corporate Law Change in this New Setting?}

What kind of changes in law might be expected given the changes and stresses just described? The governance issues raised in the activist shareholder context in the current period are at the core of traditional state corporate law so that we might expect the states to be the focal point for possible changes in law. The relative control rights of shareholders as compared to directors and managers has 
been the principal concern of state law since the reconfiguration of state and federal law in the corporate area begun in the 1890s. Further, the substance of what is being debated-concern about inappropriate shareholder interference with board governance-- fits easily within the director-centric structure that has characterized Delaware law and most other states for more than a century.

Yet Delaware law has not gone very far in exploring possible responses when the governance problem is said to be shareholder overreaching. One reason is a mismatch with the toolbox currently available to state law. As already described, Delaware law lets shareholders do only three things-vote, sell and sue, each in very limited doses. In such a setting, its courts have never had to spend a lot of time developing tools to constrain shareholder overreaching. It has often been enough to rely simply on rule \# 1 above that puts most corporate power in the hands of the board and letting them use that power to constrain particular exercises of shareholder power. See for example, the ease with which director power expanded in Unitrin to easily intrude on shareholder efforts to assert their right to sell in a takeover context and pullback in the judicial application of the more intense judicial scrutiny of Blasius to directorial interference with shareholders' right to vote which a later court has told us would only be "rarely applied." (Thompson 2016 at 420).

More specifically, the primary tool used by Delaware courts to resolve governance disputes would likely be difficult to adapt to the shareholder setting. Fiduciary duty is well-developed in cases where a manager or a board of directors have used their control over other people's money in violation of duties of loyalty or care. These duties have occasionally be extended to controlling shareholders who occupy a similar position and there have been some cases raising a parallel situation where a shareholder has a veto, but the activist setting would extend fiduciary obligations beyond traditional applications.

Thus, extending state corporate law would require building out a whole new set of rules beyond what is currently found in state law to address shareholding in public corporations in this new world of institutional shareholders. That is not to say it couldn't be done, or shouldn't be done. The changes introduced in the 1890s were even more dramatic. More recent developments such as the special litigation committee and the poison pill originally arose from private ordering of entrepreneurial lawyers. Similar approaches could find a platform in addressing the activism question within state corporate law.

Some of the suggestions made in the current debate, for example, requiring institutional shareholders, such as mutual funds, to vote in compliance with their investment policy for their beneficiaries or permitting reimbursement of non-management director nominees who cross a certain threshold of votes received, fit easily within the scope of traditional corporate law. (Strine 2014). Others require changes in tax policy or regulation of retirement plan investment that has not been the usual concern of state law. Others, like reducing the frequency of shareholder votes would require rolling back federal law that has consciously replaced state power.

Delaware's reluctance to take on this challenge reflects the historical pattern that has developed in which the state and federal governments share law-making space for corporate law. Delaware's 
preferred approach is a director-centric model that emphasizes contracting and other private ordering among key corporate constituencies. When the state wishes to intervene, its preferred tool is to adjust the rules applicable to directors. In contrast the federal government has long seen the world of corporate governance through lens shaded toward the role of shareholders. When a crash suggests the need to intervene in the state-based system, the federal government's preferred tool is mandatory rules focused on shareholder power. Of course, each actor is addressing aspects of the allocation of governance power in the corporation so that an adjustment to director power necessarily affects that allocated to shareholders and vice versa but that does not diminish the characteristic approach for each government. Congress has regularly provided rules for corporate governance but has not intruded on directors' core power to make corporate decisions. When a Delaware court needed to specify disclosure obligations in the context of a directors' conflicting interest as to a matter being voted on by shareholders eschewed promulgating such state based rules in favor of a blanket incorporation of federal law on the subject:

$$
\begin{aligned}
& \text { Federal regulations and exchange rules address disclosure of this kind in } \\
& \text { a detailed manner that balances the cost of disclosing all past } \\
& \text { relationships against the need to give stockholders information about } \\
& \text { some prior relationship that, while not rendering directors non- } \\
& \text { independent of each other, are important enough to warrant disclosure. } \\
& \text { Those bodies of authorities should not be lightly added to by our law. }{ }^{\mathrm{vi}}
\end{aligned}
$$

Several factors contribute to where Delaware ends up and its inclination not to change its law. One is a substantive preference for its longtime director-centric governance system with its ample room for private ordering and a shared power structure making use of the separate contributions of managers, directors and shareholders, characteristic of Delaware law since the late $19^{\text {th }}$ century, (as discussed above). Another is the preferences of managers and institutional shareholders for such a structure -the two groups who could upset this equilibrium if they wanted by moving to other jurisdictions. Delaware, has ample reason to get this right as home to about $60 \%$ of America's largest corporation with $20 \%$ or more of its state budget coming from incorporations. Delaware also values the sophisticated corporate bar and its nationally recognized judiciary that focuses on corporate law, bringing fame and fortune to those groups well-beyond what would be associated with a state $49^{\text {th }}$ in size and $47^{\text {th }}$ in population among the 50 states. In turn, these groups contribute to network effects and reduce the level of uncertainty, a reduction that consumers of a corporate governance system value. (Klausner 1995).

To maintain this favorable position, Delaware needs to worry about possibly simultaneous challenges in two separate dimensions: first, one or more of the other states might seek to topple Delaware from its crown just as Delaware did to New Jersey in the previous century; second, Delaware, to the extent it is able, does not want to provoke federal action preempting in the core of what remains of corporate law in the state domain. Any governance decision to alter the allocation of power between shareholders and managers, for example could upset the equilibrium. In the competition with other states the risks differ depending upon which way Delaware might move- for example toward a more director empowering position or to a more shareholder empowering position. 
There has been very little threat to Delaware's position from other states following a shareholder empowering approach. North Dakota intentionally shareholder friendly statute of 2007 has come up practically empty in terms of attracting publicly held corporations. California's statute is the best example of an older statute with views different that Delaware, but our largest state punches well below its population's share in terms number of corporations that have chosen to be governed by its law.

The challenge from states attempting to compete with Delaware by adopting more pro management laws than Delaware has been somewhat stronger. Various states have passed more antitakeover statues than Delaware, although the trend has slowed since the early 1990s. More recently a handful of states have enacted mandatory staggered boards for entities incorporated in their state, a provision seen as aiding management. The motivation driving such change and the effect of such statutes often seems to relate to a particular local company threatened by an unwanted takeover. Nevada has perhaps gone the farthest in separating itself from Delaware on this dimension, adding provision permitting waiver of fiduciary duties of loyalty in addition to antitakeover statutes. Recent studies show its effect concentrated in small firms with low institutional shareholding, but not corporations more generally. Delaware with its larger share of publicly held firms who wouldn't value a tipping of the balance between various corporate constituencies, would according to one study, lose $11 \%$ of its market share and between $\$ 35-70$ million per year in franchise taxes if it changed its laws to adopt stronger management protections as in Nevada: "Nevada does not seem to create pressure on Delaware to cater to managerial interest." (Eldar \& Magnolfi 2016 at 4). From the perspective of a race among the states, there seems little reason for Delaware to move from its sweet spot

In looking at the interaction with the federal government, the result seems to be the same. The pattern for most of 120 years has been for the federal law to step in when the balance of state law went awry (Roe 2003). This interaction has usually produced a change in in one direction, toward greater empowerment of shareholders. If Delaware were to step in to limit the power of shareholders, such action increases the likelihood of a federal response as occurred already in this century in SarbanesOxley and Dodd-Frank. Even if Delaware wanted to legislate to increase the power of shareholders it would be competing against an already large federal footprint. Why should the state modify corporate law rules to lean toward shareholders, when the federal inclination in making laws relating to corporations over the last 80 year leans so much in the direction of adding provisions for shareholders? And why should Delaware modify corporate rules to lean toward directors or managers when it may simply provoke federal response to take more or all of corporate law under the wing of federal law?

Might a period of significant federal deregulation in the Trump administration change this pattern? After all, a prior such period in the early 1980s produced perhaps the most significant deviation from the law-making pattern described here, at least on the Delaware side. The Unocal, Revlon \& Blasius fiduciary duty standards developed in those years held the possibility of significant limits on director discretion. (Davidoff Solomon \& Thomas 2016). A couple of factors point to a narrow impact of such a scenario. The still interstitial footprint of existing federal corporate governance rules, even after 80 years of federal lawmaking, suggest that any particular federal action likely will not disrupt the overall pattern. The less "bang for the buck" for any such interstitial rollbacks likely pushes such changes down the deregulatory agenda. On the state side, as discussed above, the director-centric approach of Delaware 
law and the judicial reliance on director fiduciary duty are not well-suited to provide new rules focused on activist shareholders. Delaware corporate law remains focused on managers and, to a lesser extent, shareholders. Employees, consumers and other corporate constituencies are still likely to prefer pursuing corporate law-making in the federal forum. (Roe 2003). Benefit corporation legislation, opening up state corporate law to corporate purposes beyond shareholder wealth maximization is another possible avenue of change in state law. (Kassoy, Houlahan, \& Coen Gilbert, 2016) Ensconced in the non-mandatory, private ordering pattern of Delaware and other state corporations laws and therefore applicable only if managers and shareholders choose this alternative, this model also seems unlikely, at the moment, to substantially change the current balance at state law.

\section{Conclusion}

In the current federal-state world that has grown up in corporate law, there seems little likelihood of any significant move in state law. For 120 years Delaware has followed a director-centric structure to its corporate law that emphasizes ample room for private ordering and for key parties in the internal governance of the corporation to push back and forth among themselves about particular governance issues governance. For about the same amount of time, the federal government has periodically intervened in with regulation aimed at large, publicly held corporations to protect consumers or workers and sometimes to empower shareholders, but not to erase the longstanding internal governance system of state corporations statutes. This bifurcated approach to corporate law contributes to the static nature of law-making in the state realm. Delaware's director-centric/private ordering approach for governance in large publicly held corporations faces little real challenge from other states who may seek to be more shareholder empowering than Delaware or more friendly to management. Delaware must pay constant attention to the possibility of federal incursion. Yet, the pattern that each has chosen to followDelaware focus on directors and the federal focus on shareholders has facilitated a "stay in your lane" approach by each in terms of how they implement what are essentially inconsistent approaches to regulation. The result is likely to be a continued pattern of static state law and periodic change in federal law, likely in response to a crash. 
References

Arsht, S. Samuel, 1976, The History of Delaware Corporation Law, 1 DEL. J. CORP. 1.

Badawi, Adam, 2014. Influence Costs and the Scope of Board Authority, 39 J. CORP. LAW 675.

Banner, Stuart, 1997, What Causes New Securities Regulation, 75 WASH. U. L. Q. 849.

Blair, Margaret and Elizabeth Pollman, 2015, The Derivative Nature of Corporate Constitutional Rights, 56 WM. \& MARY L. REV. 1673.

Blumberg, Phillip A., 1990, The Corporate Entity in an Era of Multinational Corporations, 15 DEL. J. CoRP. L. 283, 301.

Bostwick, C., 1899, Legislative Competition for Corporate Capital.

Butler, Nicholas Murray, 1912, Why Should We Change Our Form of Government: Studies in Practical Politics.

Cary, William, 1974, Federalism and Corporate Law: Reflections upon Delaware, 83 YALE L. J. 663

Davidoff Solomon, Steven and Randall S. Thomas, 2016, The Rise and Fall of Delaware Takeover Standards.

Chandler, Alfred D. Jr., 1977, The Visible Hand, The Managerial Revolution in American Business, (Belnap Press).

Dodd, E. Merrick, 1936, Statutory Developments in Business Corporation Law 1886-1936, 50 HARV. L. ReV. $27,40$.

Edelman Paul, Randall S. Thomas \& Robert B. Thompson, 2014, Shareholder Voting in an Age of Intermediary Capitalism, 87 S. CAL. L. ReV. 1359.

Eisenberg, Melvin A., 1976 The Structure of Corporate Law.

Eldar, Ofer and Lorenzo Magnolfi, 2016. Regulatory Competition and the Market for Corporate Law, Yale Law \& Economics Working Paper \#528.

Ellis, Joseph, 2015 The Quartet: Orchestrating the Second American Revolution 1783-1789. (Alfred A. Knopf).

Gilson, Ronald J. \& Jeffrey N. Gordon, 2013, The Agency Costs of Agency Capitalism: Activist Investors and the Revaluation of Governance Rights, 113 CoLUM. L. REV. 863, 897.

Hamil, Susan Pace, 1999, From Special Privilege to General Utility: A Continuation of Willard Hurst's Study of Corporations, 49 AM. U. L. REV. 81.

Hilt, Eric, 2008, Democratizing Incorporations: Law of Industrial Enterprises in Massachusetts 1830-1880.

Hilt, Eric, 2015, Corporations Law and the Shift Toward Open Access in the Antebellum United States, National Bureau of Economic Research Working Paper \# 21195. 
Horwitz, Morton J., 1986, Santa Clara Revisited: The Development of Corporate Theory, 88 W. VA. L. REV. 173.

Kassoy, Andrew, Bart Houlahan, and Jay Coen Gilbert, Impact Governance and Management: Fulfilling the Promise of Capitalism to Achieve a Shared and Durable Prosperity, Brookings, Institute, July 1, 2016https://www.brookings.edu/research/impact-governance-and-management-fulfilling-the-promiseof-capitalism-to-achieve-a-shared-and-durable-prosperity/

Klausner, Michael, 1995. Corporations, Corporate Law, and Networks of Contracts, 81 VA. L. REV. 757.

Livermore, Shaw, 1939, Early American Land Companies, Their Influence on Corporate Development (Commonwealth Fund).

Maitland, William, 1902, Preface to Maitland's English Translation of Otto Gierke, Political Theories of the Middle Ages.

Navin, Thomas R. \& Marian V. Sears, 1955, The Rise of a Market for Industrial Securities, 1887-1902, 29 BUS. HIST. REV. 105, 106.

Roe, Mark, 2003, Delaware's Competition, 117 HARV. L. ReV. 588.

Rutledge, Wiley D., 1937, Significant Trends in Modern Incorporation Statutes, 22 WASH. U. L. Q. 305.

Schwartz, Donald E, 1978, In Search of Corporate Soul, The Structure of the Corporation: By Melvin Aron Eisenberg, 87 YALE L.J. 685, 688.

Seligman, Joel, 1976, A Brief History of Delaware's General Corporation Law of 1899, 1 DEL. J. CORP. L. 249.

Smith, D. Gordon, 1998, The Shareholder Primacy Norm, 23 J. CORP. L. 277.

Strine, Jr., Leo, 2014, Can We Do Better by Ordinary Investors? A Pragmatic Reaction to the Dueling Ideological Mythologists of Corporate Law, 114 CoLUM. L. REV. 449.

Strine Jr. Leo E. and Nicholas Walter, Originalists or Original: The Difficulties of Reconciling Citizens United with Corporate Law History.

Thompson, Robert B., 2016, Anti-Primacy; Sharing Power in American Corporations, 71 Bus. LAW. 381.

Thompson, Robert B., 2014, Mergers, and Acquisitions: Law and Finance (2d. ed.)

Thompson, Robert B. and Hillary A. Sale, 2003, Securities Fraud as Corporate Governance: Reflections Upon Federalism, 56 VAND. L. ReV. 859

Yablon, Charles 2007, Historic Race Competition for Corporate Charters and the Rise and Decline of New Jersey, 1880-1910, 32 J. CORP. L. 355.

Winter, Ralph 1977, State Law, Shareholder Protection and the Theory of the Corporation, 6. J. LEGAL STUD. 251. 
* Peter P. Weidenbruch Jr. Professor of Business Law, Georgetown University Law Center.

' Bank of Augusta v. Earle, 38 U.S. (5 Pet.) 517 (1839).

ii The trust concept had a long history in Anglo-American corporate law as a means to organize entities without a charter from the crown in earlier centuries. See Frederic William Maitland, Preface to Maitland's English translation of Otto Gierke, Political Theories of the Middle Ages (1902) at xxix. ("Behind the screen of trustees and concealed from the direct scrutiny of legal theories all manners of groups could flourish.")

iii Liggett Co. v. Lee, 288 U.S. 517, 550-54 (1933) (Brandeis dissenting).

iv Del. General Corporation Act (1899) §20. The major difference is the phrase "or under the direction of" that was added late in the $20^{\text {th }}$ century. Delaware's 1899 Act in large parts tracked the 1896 New Jersey statute.

v 1899 §20. 1899 §17 The 1899 statue was the first Delaware to contain consolidation (merger) provision by a supermajority vote of shareholders, which previously would have required unanimous action. $1899 \S 54$

vi In re Netsmart Technologies, Inc. Shareholders Litigation, 924 A. 2d 171, 206 (Del. Ch. 2007). 